\title{
Ultrasonication of H-MOR zeolite catalysts for dimethylether (DME) production as a clean fuel
}

\author{
Ahmed K. Aboul-Gheit ${ }^{1}$, Sameh M. K. Aboul-Fotouh ${ }^{2,3 *}$, Laila I. Ali ${ }^{2}$ and Mona A. Naghmash ${ }^{2}$ \\ ${ }^{1}$ Egyptian Petroleum Research Institute, Cairo 11787, Nasr City, P.O. Box 9540, Cairo, Egypt. \\ ${ }^{2}$ Chemistry Department, Faculty of Education, Ain Shams University, Roxy, Cairo 11757, Egypt. \\ ${ }^{3}$ Chemistry Department, Faculty of Science, Northern Border University, Kingdom of Saudi Arabia.
}

Received 9 April, 2014; Accepted 29 July, 2014

\begin{abstract}
All important effective ultrasonication variables encountered during carrying out the dehydration of methanol on H-MOR zeolite catalysts to produce dimethylether are studied in the present communication. These variables include; (a) the type of ultrasonication media, (b) the ultrasonication period, and (c) the volume of the ultrasonication liquid media per a given weight of the solid zeolite catalyst. Scanning electron microscope (SEM) photographs of the zeolite have clarified that methanol by itself used as an ultrasonication medium gives the best results concerning the homogeneity of particle sizes compared to the untreated catalyst, where large agglomerates and non-homogeneous clusters appeared. Water used as a sonicated medium showed many large agglomerates in addition to some smaller particles. The d-spacing values obtained from XRD data were plotted as a function of ultrasonication period and volume of methanol per gram of the zeolite in fixed volume of the different alcohols examined. All these data were found to give precise correlation with the catalytic activity of the sonicated H-MOR zeolite. These findings certified that ultrasonication has a deep effect on the unit cell resolution and hence on the catalytic behavior of the dehydration of methanol to dimethyl ether (DME). $\mathrm{NH}_{3}$-TPD shows that ultrasound irradiation has enhanced the acidity of $\mathrm{H}-\mathrm{MOR}$ catalyst and hence it is catalytic performance for DME formation.
\end{abstract}

Key words: Ultrasonication, H-MOR, dimethyl ether (DME), methanol.

\section{INTRODUCTION}

A growing awareness of climate change, air pollution and energy consumption necessitates the development of clean, renewable and sustainable fuels. In terms of small energy generators for either fixed or mobile power sources there is a number of existing technologies, of which diesel engines are common. However, unless legislated against, such engines produce exhaust streams with significant amounts of NOx, SOx and particulates. Furthermore, diesel exhausts have been linked to cancer (Paddock, 2012) in a recent World Health Organization report, thus clean alternatives are again desired (Yaripour et al., 2005). Dimethyl ether (DME) is one of the most promising ultra clean, renewable and oxygenated alternative fuel for diesel engines. The reasons for this are numerous and include its lower auto-ignition temperature (cetane number, $\mathrm{CN}>$ 
55), higher oxygen content and C-O-C molecular structure. DME can be easily evaporated (Zhu et al., 2012), is non-toxic, non-carcinogenic and non-corrosive. It is also considered as an environmentally friendly compound because of its low global warming potential over both short and long time horizons (Ladera et al., 2012).

Methanol to dimethyl ether (MTD) dehydration over a solid acid catalyst in a fixed bed reactor was first reported by Mobil in 1965 . Since then, many methanol dehydration catalysts have been examined (Keshavarz et al., 2011) including $\mathrm{Y}^{-\mathrm{Al}_{2} \mathrm{O}_{3}}$ (Yaripour et al., 2005; Keshavarz et al., 2011; Raoof et al., 2008; Khom-in et al., 2008; Mollavali et al., 2009; Ebeid et al., 1993; Amin et al., 1994), crystalline aluminosilicates (Amin et al., 1994; Liu et al., 2011), zeolites (ZSM-5) (Jiang et al., 2004), clays (Sun et al., 2003) and phosphates such as aluminum phosphate (Lertjiamratn et al., 2010; Yaripour et al., 2005). However the most common catalysts used are $\mathrm{Y}^{-} \mathrm{Al}_{2} \mathrm{O}_{3}$ and zeolites. The activity of $\mathrm{H}$-zeolites has been reported for the dehydration of methanol to DME (Fei et al., 2006; Fu et al., 2005; Khandan et al., 2008; Ramos et al., 2005; Xu et al., 1997).

Some zeolites are not active enough and/or deactivated rapidly due to applying high dehydration temperatures, strong acidity and wide pores ( $\mathrm{Xu}$ et al., 1997; Fu et al., 2005; Wang et al., 2002) which result in low selectivity to DME. So, extensive research has been focused on finding better catalysts which have higher catalytic activity, higher stability, complete selectivity for DME and fewer tendencies to generate hydrocarbons and coke (Yaripour et al., 2005). Recent studies have shown that solid catalysts including medium to weak acid sites are desirable for DME production and catalyst stability so, several modifications were focused on the adjustment of catalyst acidity (Yaripour et al., 2005; Kim et al., 2006).

$\mathrm{H}$-Mordenite has been found to acquire many exiting textural and structural properties that are not acquired by other catalytic materials. Although this zeolite, like other zeolites, is a microporous material, its pores are wide enough to allow many reactions to be achieved with very high selectivities (Aboul-Gheit and Aboul-Fotouh, 2012; Aboul-Fotouh, 2003).

Aboul-Fotouh and Hassan (2010) and Khandan et al. (2008, 2010) studied the effect of modified H-Mordenite with different metal oxides on methanol dehydration to DME. The results indicated that $\mathrm{H}$-Mordenite modified with $\mathrm{CuO}$ and $\mathrm{Al}_{2} \mathrm{O}_{3}$ was the best catalyst. Also, they found that with increasing the $\mathrm{Si} / \mathrm{Al}$ ratio the conversion and selectivity were reduced. Also, Aboul-Fotouh et al. (2011) have found that fluorination of $\mathrm{H}$-mordenite gives higher dehydration of methanol to DME via enhancing the zeolite acidity.

Recently, the application of ultrasound for investigating different chemical reactions and catalyst synthesis is of interest by various researchers (Kumar et al., 2007; Zhang et al., 2008). Significant changes have been commonly observed in the processes and properties of the reaction products in the presence of ultrasound. The main purpose of using ultrasound in different chemical reactions has been to enhance the reaction rates, yields and selectivity of the desired product. There are some published papers in the literature on the use of ultrasound irradiation in zeolite synthesis and catalyst preparation (Zhang et al., 2008; Bonrath, 2005; Simona and Antonella, 2003; Dantsin and Suslick, 2000).

Aboul-Fotouh (2013) studied the effect of ultrasonic irradiation and/or halogenation on the catalytic performance of $\mathrm{Y}-\mathrm{Al}_{2} \mathrm{O}_{3}$ for methanol dehydration to dimethyl ether. The results indicated that the halogenated alumina catalysts prepared under the effect of ultrasonic irradiation showed higher performance of $\mathrm{y}-\mathrm{Al}_{2} \mathrm{O}_{3}$ for DME formation. Also, Aboul-Fotouh (2014) studied the effect of ultrasonic irradiation on the preparation of $\mathrm{CuO} / \mathrm{ZnO} / \mathrm{Y}$ $\mathrm{Al}_{2} \mathrm{O}_{3}$ for methanol dehydration to dimethyl ether. The results indicated that the $\mathrm{CuO} / \mathrm{ZnO} / \mathrm{Y}-\mathrm{Al}_{2} \mathrm{O}_{3}$ catalysts prepared under the effect of ultrasonic irradiation showed higher activity for DME formation.

The aim of the present work is to study the factors affecting ultrasonication efficiency on H-MOR zeolite catalyst for the dehydration of methanol to dimethyl ether (DME).

\section{EXPERIMENTAL}

\section{Preparation of the catalysts \\ H-Mordenite (H-MOR) catalyst}

The sodium ions in Na-mordenite zeolite (Zeolon 900-Na), kindly supplied by Norton Co., USA, in the form of $1 / 16^{\|}(1.59 \mathrm{~mm})$ extrudates, were exchanged with $\mathrm{NH}_{4} \mathrm{NO}_{3}$ molar solution for five times under reflux, each time with a fresh solution for $8 \mathrm{~h}$ at $70^{\circ} \mathrm{C}$. The zeolite was then separated, washed with distilled water till free of the $\mathrm{NO}_{3}{ }^{-}$, dried at $110^{\circ} \mathrm{C}$ overnight then calcined in air at $550^{\circ} \mathrm{C}$ for $3 \mathrm{~h}$. The $\mathrm{H}$ - form $(\mathrm{H}-\mathrm{MOR})$ acquired a Si/Al ratio of 6.1 , surface area of $401.1 \mathrm{~m}^{2} \mathrm{~g}^{-1}$ ), effective pore diameter of $6.7 \AA$ and pore volume $0.27 \mathrm{~cm}^{3} \mathrm{~g}^{-1}$.

\section{Ultrasonicated H-MOR catalysts}

$0.3 \mathrm{~g}$ of the obtained H-MOR was ultrasonicated in $7.5 \mathrm{~cm}^{3}$ methanol as a liquid carrier for $20,40,60$ or 80 min using UP5OH sonication probe $(30 \mathrm{kHz}, 50 \mathrm{w})$ at room temperature then centrifuged for $30 \mathrm{~min}$ to separate the zeolite from the methanol carrier. The catalyst was dried at $110^{\circ} \mathrm{C}$ overnight and calcined at $530^{\circ} \mathrm{C}$ for $2 \mathrm{~h}$. A set of ultrasonicated experiments was carried out using different carriers; ethanol, n-propanol, n-butanol or distilled water. Another set of experiments was also carried out using different volumes $\left(5.0,7.5,10\right.$ and $\left.12.5 \mathrm{~cm}^{3}\right)$ of methanol/ $0.3 \mathrm{~g}$ of $\mathrm{H}$ MOR powder.

\section{Hydroconversion reactor system and reaction product analysis}

A silica glass flow - type tubular reactor system loaded with $0.1 \mathrm{~g}$ of the zeolite catalyst was used. The reactor was heated in an insulated wider silica tube jacket, thermostated to $\pm 1^{\circ} \mathrm{C}$. Argon was 
Intensity

(a.u)

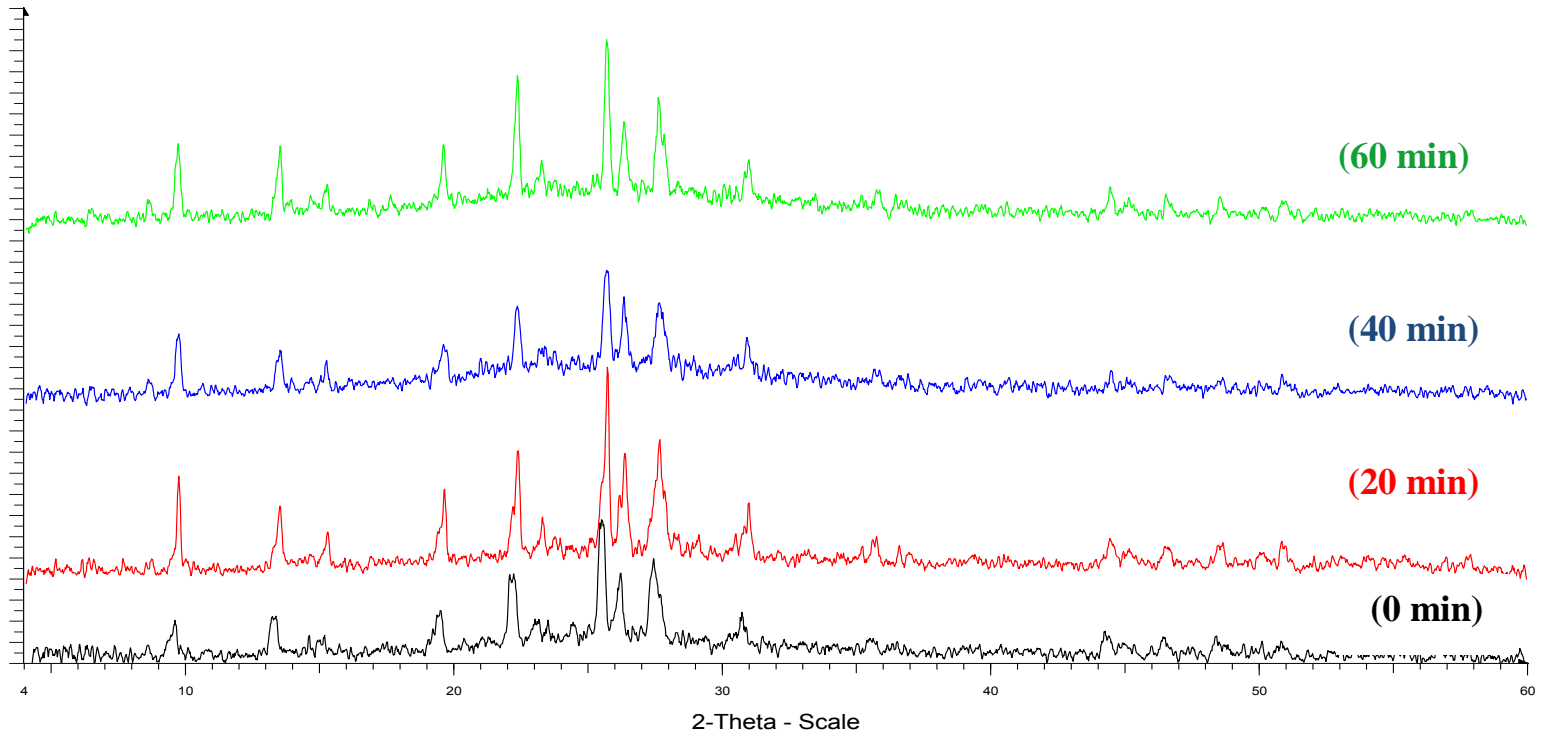

Figure 1. XRD diffractograms for H-MOR ultrasonicated for different period.

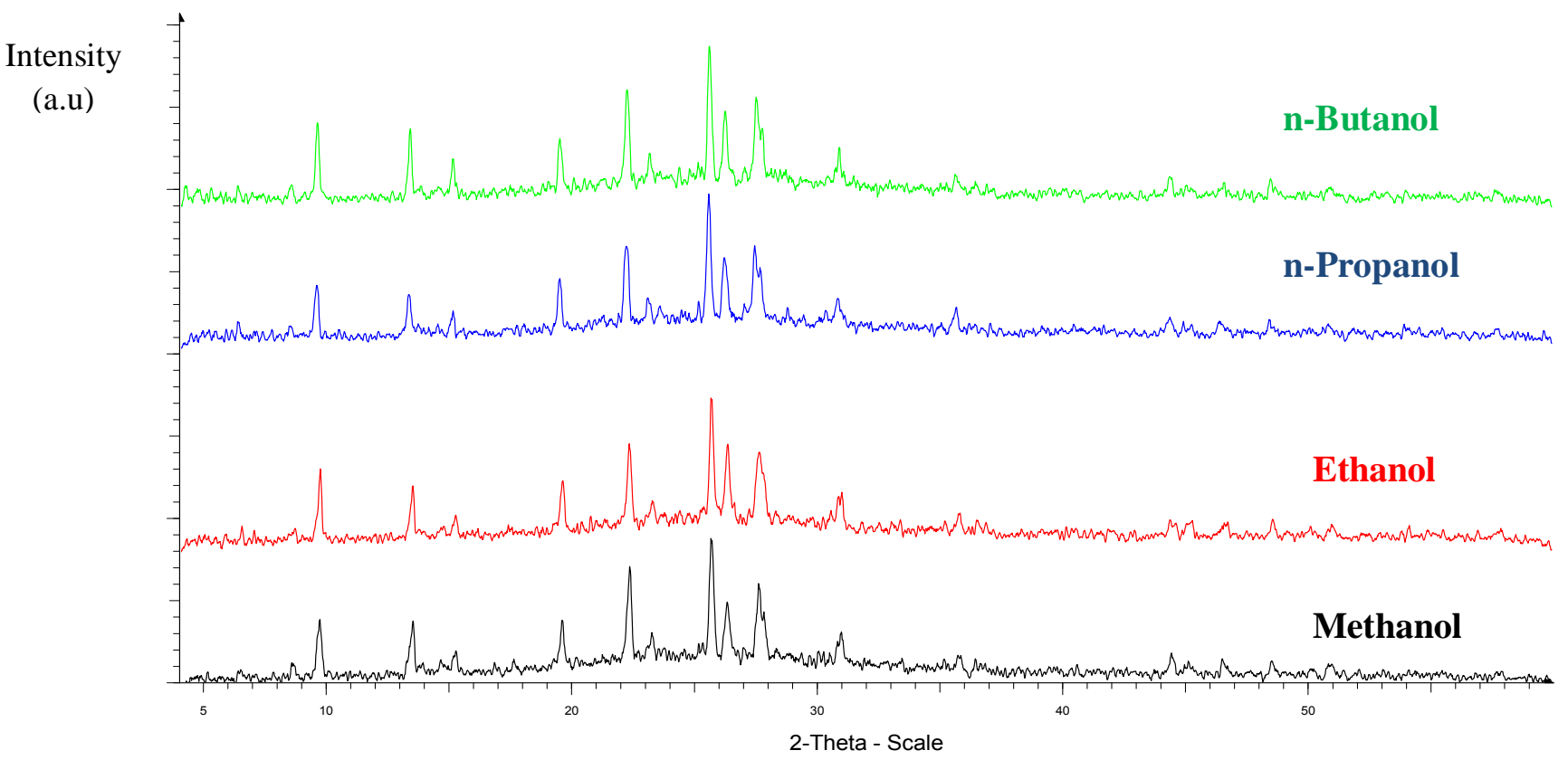

Figure 2. XRD diffractograms for H-MOR ultrasonicated with different media.

used as a carrier gas at a flow rate of $30 \mathrm{~cm}^{3} \mathrm{~min}^{-1}$ in all runs. The methanol feed was introduced into the reactor via continuous evaporation applying argon flow passing into a closed jar thermostated at a fixed temperature of $26^{\circ} \mathrm{C}$, whereby the quantity of methanol was always $4.98 \times 10^{-2}$ mole $^{-1}$. The reaction runs were investigated at temperatures ranging between 100 to $300^{\circ} \mathrm{C}$, with $25^{\circ} \mathrm{C}$ increments. The reaction product was analysed using a Perkin-Elmer Autosystem XL gas-chromatograph with a $4 \mathrm{~m}$ long column, packed with $10 \%$ squalane plus $10 \%$ didecyl phthalate supported on chromosorb W-HP of 80-100 mesh. A flame ionization detector and a Totalchrom Navigator Programme computed were used.

\section{X-ray diffraction patterns of the current catalysts}

The X-ray diffraction patterns of the current catalysts were carried out using a Phillips X, Pert Diffractometer PW 1390 at $40 \mathrm{kV}$ and 30 $\mathrm{mA}$ with $\mathrm{Ni}$ Filter and $\mathrm{Cu}$ Kò radiation. The XRD runs were carried out up to $2 \theta$ of $60^{\circ}$. The traditional XRD patterns obtained for the current catalysts show more or less similar $2 \theta$ of the diffraction peaks. The XRD patterns (Figures 1 to 3 ) have been used to obtain the $d$-spacing values of the unit cell of the zeolite samples under investigation and the values necessary for calculating the crystallite size using the Scherer's equation. The XRD data are given in Table 1. 


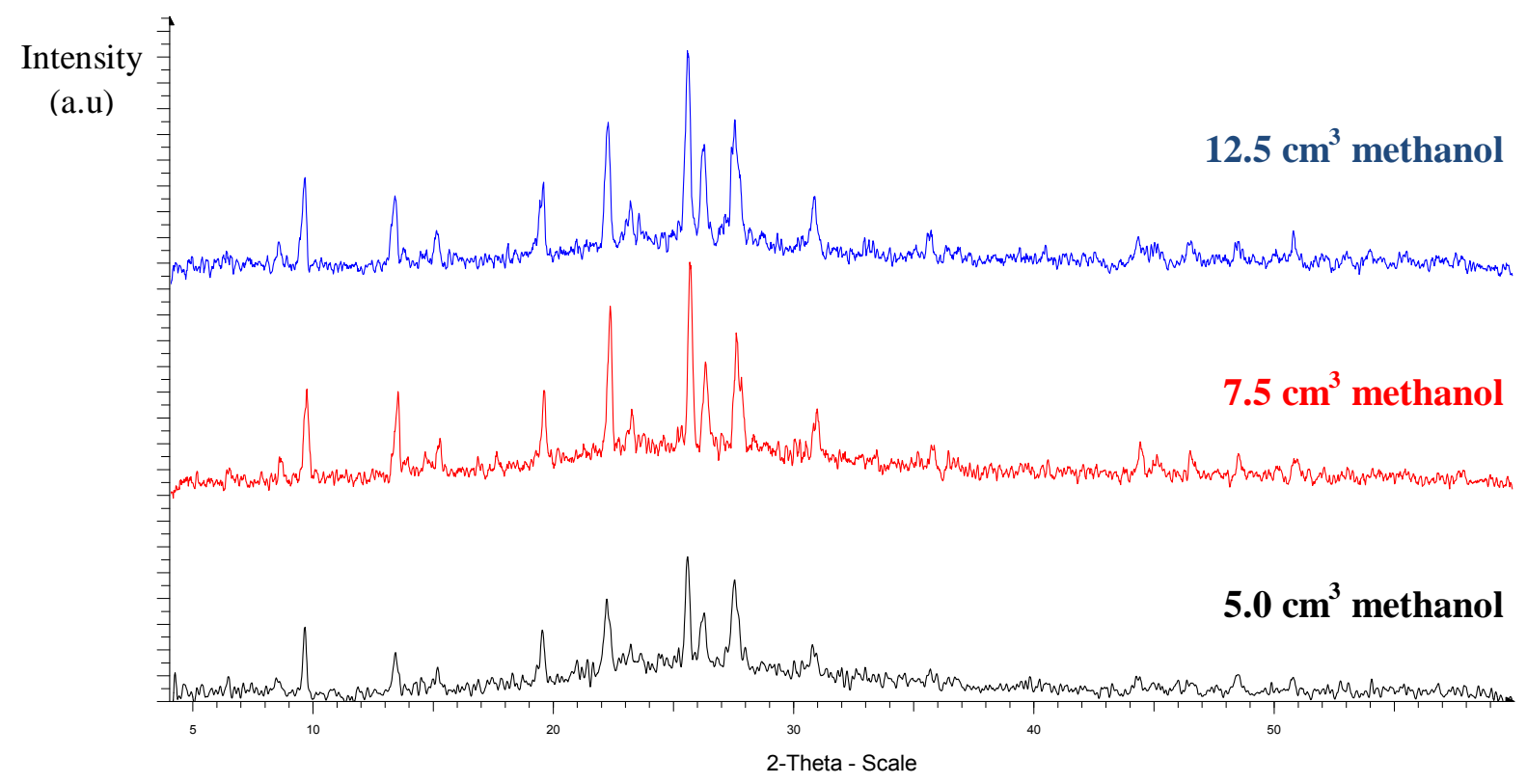

Figure 3. XRD diffractograms for H-MOR ultrasonicated with different volume of methanol.

Table 1. Surface characterization of H-MOR catalysts.

\begin{tabular}{lcc}
\hline Catalysts & $\mathbf{S}_{\mathrm{BET}}\left(\mathbf{m}^{\mathbf{2}} / \mathbf{g}\right)$ & Crystallite size $(\mathbf{n m})$ \\
\hline Ultrasonication time $(\mathbf{m i n})$ & & \\
00 & 401.1 & 43.8 \\
20 & 413.4 & 40.0 \\
40 & 464.1 & 38.3 \\
60 & 499.0 & 32.6 \\
80 & 410.1 & 41.5 \\
Type of ultrasonication media & & \\
Methanol & 499.0 & 32.6 \\
Ethanol & 395.1 & 50.0 \\
$\mathrm{n}-\mathrm{Propanol}$ & 389.7 & 60.2 \\
$\mathrm{n}-\mathrm{Butanol}$ & 385.7 & 64.3 \\
Water & 282.6 & 52.7 \\
& & \\
Volume of ultrasonication liquid & & 47.8 \\
$5.0 \mathrm{~cm}^{3}$ methanol & 396.1 & 32.6 \\
$7.5 \mathrm{~cm}^{3}$ methanol & 499.0 & 41.0 \\
$12.5 \mathrm{~cm}^{3}$ methanol & 413.3 & \\
\hline
\end{tabular}

\section{Scanning electron microscope (SEM)}

SEM photographs were obtained for the H-MOR samples mounted on aluminum slabs and sputter-coated with a thin gold layer of $\sim$ $150 \AA$ thicknesses using an Edward sputter-coater. The samples were then examined in a scanning electron microscope model JSM5410 with Electron probe micro analyzer (JEOL) at $30 \mathrm{kV}$.

\section{Surface characterization}

The surface characteristics of the catalysts were measured using the $\mathrm{N}_{2}$ adsorption-desorption isotherm at liquid nitrogen temperature $\left(-196^{\circ} \mathrm{C}\right)$, using surface area and pore size analyzer Quntachrome -Auto Sorb-1mon. The pore size distribution curves were calculated according the BJH method applying the desorption values.

\section{Temperature programmed desorption (TPD) of ammonia}

The TPD of presorbed ammonia on the acid sites of the zeolite supports was carried out in differential scanning calorimeter (DSC) using nitrogen as a purge gas according to the procedure adopted 


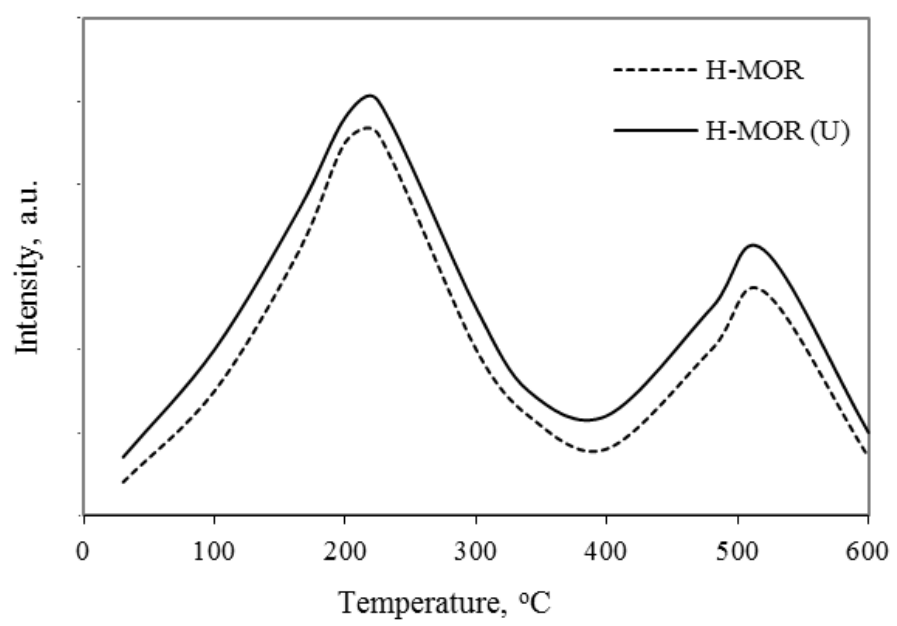

Figure 4. $\mathrm{NH}_{3}$-TPD for $\mathrm{H}-\mathrm{MOR}$ catalysts before and after ultrasonication $\left(7.5 \mathrm{~cm}^{3}\right.$ methanol and $\left.60 \mathrm{~min}\right)$.

Table 2. Ammonia TPD of the H-MOR catalysts.

\begin{tabular}{lcc}
\hline \multirow{2}{*}{ Catalysts } & \multicolumn{2}{c}{ Acid sites strength distribution } \\
\cline { 2 - 3 } & $\Delta \mathbf{H}_{\mathrm{d}}\left(\mathbf{J g}^{-1}\right)^{\mathbf{a}}$ & Peak temperature $\left(\mathbf{T}_{\max }{ }^{\circ} \mathbf{C}\right)^{\mathbf{b}}$ \\
\hline H-MOR & 92.2 & 528 \\
H-MOR $(U)^{\mathrm{c}}$ & 98.3 & 532 \\
\hline${ }^{\text {a }}$ Proportional to acid sites number. & ${ }^{\mathrm{b}}$ & Proportional to acid sites strength. \\
${ }^{c}$ Condition: $7.5 \mathrm{~cm}^{3}$ methanol and 60 min.
\end{tabular}

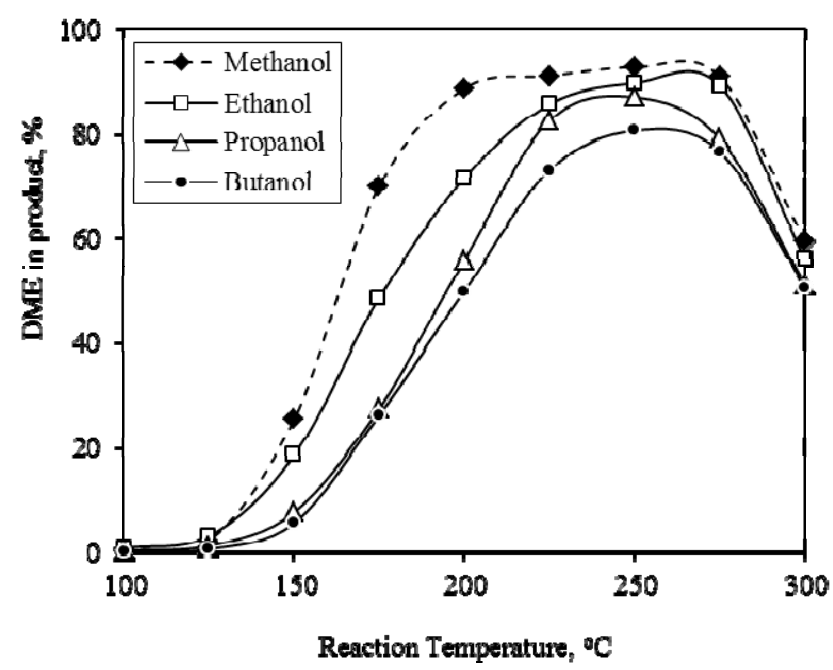

Figure 5. Effect of alcoholic ultrasonication media on the formation of DME using H-MOR catalyst.

by Freel (1972). The thermograms obtained (Figure 4) for H-MOR samples show two peaks; a low-temperature peak corresponding to the ammonia desorption enthalpy $\left(\Delta \mathrm{H}_{\mathrm{d}}\right)$ from the weak acid sites of the catalyst and a high temperature peak corresponding to the ammonia desorption enthalpy from the strong acid sites. The $\Delta H_{d}$ values were proportional to the number of acid sites, whereas the peak temperature $\left(T_{\max }\right)$ was taken to correlate the acid sites strength of the catalysts; the higher the $T_{\max }$ value, the stronger the acid sites in the catalyst (Table 2).

\section{RESULTS AND DISCUSSION}

\section{Effect of ultrasonication media}

It has been distinguished that there are some practically important factors that affect the role of ultrasonication of catalytic materials. We have investigated these factors as related to their influence upon the catalytic activity of $\mathrm{H}$ MOR zeolite acting as catalysts for methanol conversion to dimethylether (DME). Of these factors, we examined the influence of solvent type or more specifically the liquid medium in which the sonicating probe is immersed. Most frequently, it has been observed in the published literature that an alcohol was used, hence, in the present work; we examined a homologous series of lowmolecular weight alcohols, namely; methanol, ethanol, npropanol and n-butanol. It has been found that, the most effective alcohol is methanol followed by ethanol, then propanol and finally n-butanol (Figure 5). This can be attributed to a decreasing polarity with increasing the 


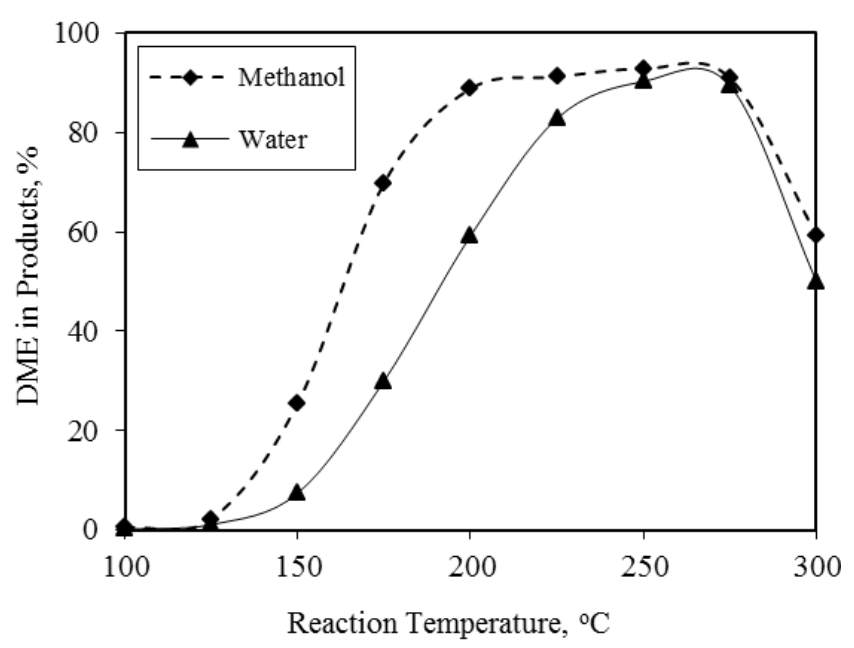

Figure 6. Effect of aqueous and methanol as ultrasonication media on the formation of DME using H-MOR catalyst.

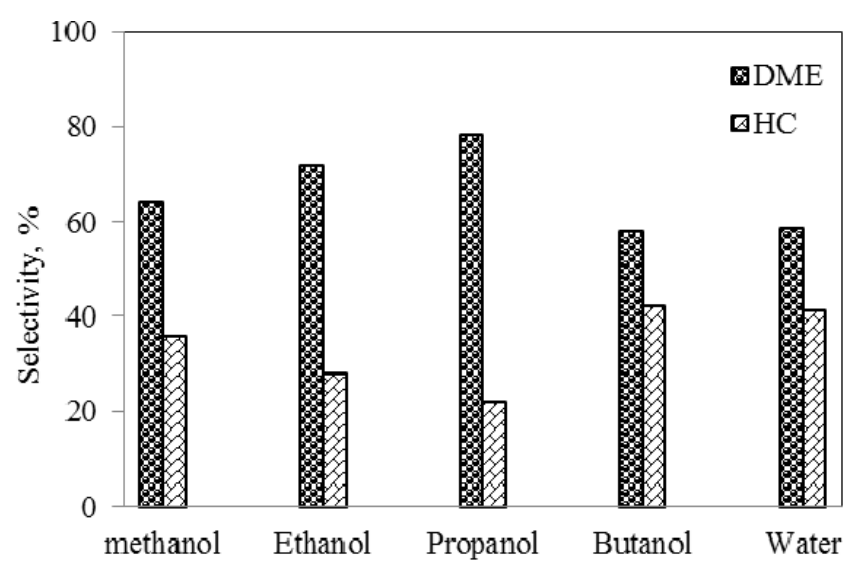

Figure 7. Effect of ultrasonication media on DME and $\mathrm{HC}$ selectivities at $300^{\circ} \mathrm{C}$.

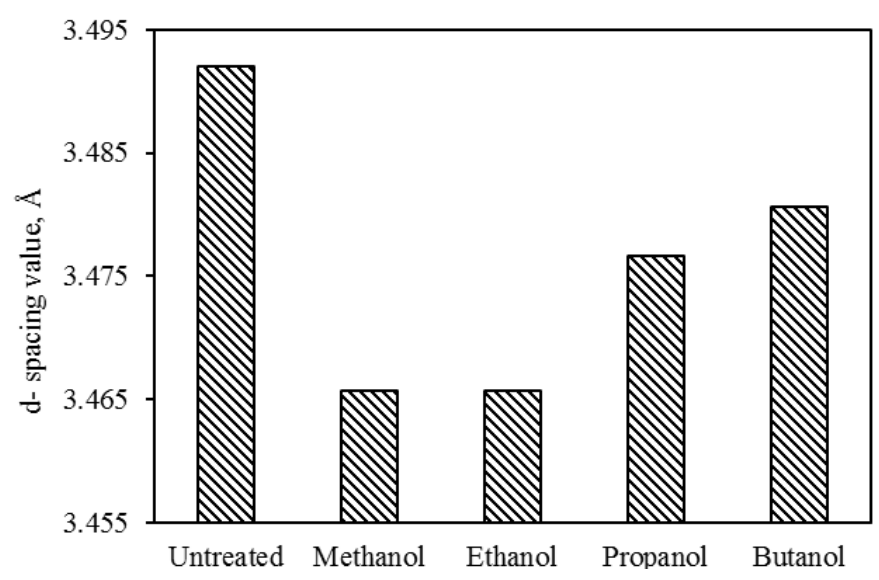

Figure 8. Effect of ultrasonication media on the d-spacing value of $\mathrm{H}-\mathrm{MOR}$ catalyst. hydrocarbon portion relative to the hydroxyl group in the alcohol used, and also attributed to increasing the surface area and decreasing the nanoparticle size using low-molecular weight alcohols (methanol) as a sonication medium (Table 1) as well as increasing the acidity of $\mathrm{H}$ MOR catalyst after ultrasonication (Table 2 and Figure 4).

Figure 6 also shows that methanol is significantly advantageous in comparison with all other current alcohols particularly during the lower temperature range $\left(125-225^{\circ} \mathrm{C}\right)$. For instance, in methanol as sonication medium, at $200^{\circ} \mathrm{C}$ reaction temperature, DME production comprises $88.8 \%$, whereas in presence of ethanol, npropanol or n-butanol, DME comprises $71.5,55.7$ or $49.8 \%$, respectively. On the other hand, Figure 6 shows that water which is also frequently used as a sonication medium is a less effective sonication medium than methanol, where DME formation comprises $59.2 \%$ at $200^{\circ} \mathrm{C}$. This can be attributed to increasing the particle seizes with decreasing the surface area using water as a sonication medium (Table 1).

Beyond $250^{\circ} \mathrm{C}$, a decline of DME yield occurs, evidently due to the formation of hydrocarbons; namely, ethylene, propylene, and butylene. These hydrocarbons acquire larger carbon contents that lead to catalyst deactivation (Sun et al., 2003; Ramos et al., 2005; AboulFotouh, 2014; Bandiera and Naccache, 1991).

Figure 7 shows the selectivities of the current methanol dehydration reaction at $300^{\circ} \mathrm{C}$ producing DME together with olefinic hydrocarbons $(\mathrm{HC})$ using different media while sonicating the H-MOR zeolite catalyst, where the selectivity of DME is determined as follows:

Selectivity $=$ DME $\times 100 /$ DME + hydrocarbons

Evidently, the DME selectivity is enhanced with changing the alcohol sonication medium from methanol up to $n-$ propanol through ethanol then decreases in n-butanol. On the contrary, the selectivity for olefins formation decreases to a minimum in propanol then increases in $\mathrm{n}$ butanol. Water medium gives a similar behavior as using the n-butanol medium for sonicating the H-MOR catalyst. Figure 8 shows the change of the unit cell d-spacing obtained from XRD data on ultrasonicating the H-MOR catalyst sonicated for $60 \mathrm{~min}$ in methanol solvent of 7.5 $\mathrm{cm}^{3} / 0.3 \mathrm{~g} \mathrm{H}-M O R$. The figure shows that the $\mathrm{d}$ - spacing value is as high as $3.4920 \AA$ using the untreated $\mathrm{H}$-MOR zeolite that drops significantly to $3.4657 \AA$ using methanol as a sonication medium.

Ethanol gives a slightly higher d-spacing then continually increases with increasing the molecular weight of the alcoholic medium. This behavior is in accordance with the performance of DME production (Figure 5) since a true impact of the solvent polarity on the crystalline structure of the zeolite occurs.

An additional proof of the clusters formation or dissociation can be evident in Figure 9 which presents the SEM photograph showing highly agglomerated 


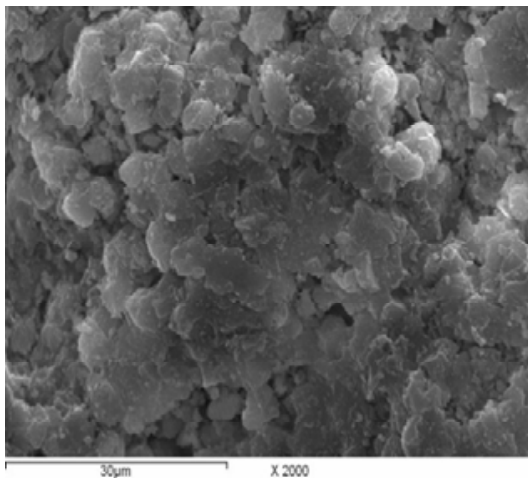

(a) Untreated

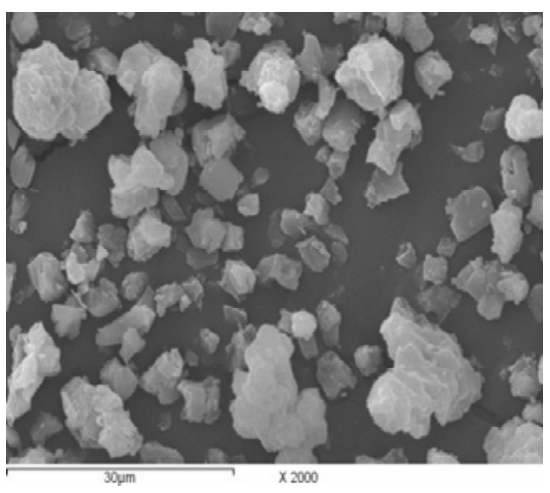

(c) Butanol

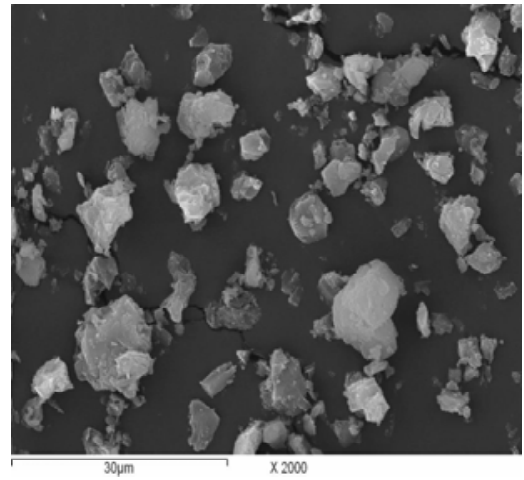

(b) Methanol

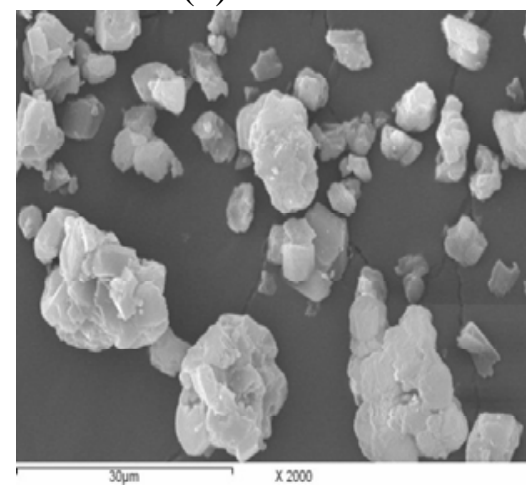

(d) Water

Figure 9. SEM of ultrasonicated H-MOR using different media.

clusters of the untreated H-MOR (Figure 9a). However, the photographs in Figures $9 \mathrm{~b}, \mathrm{c}$ and $\mathrm{d}$ obtained for the $\mathrm{H}-\mathrm{MOR}$ sonicated for $60 \mathrm{~min}$ in methanol, n-butanol and water, respectively, show systematic differences of agglomerated clusters in these media that accord closely with the surface area and crystallite size (Table 1) and the catalytic activities (Figures 5 and 6 ) of the current ultrasonicated catalysts. Evidently, the crystallites of $\mathrm{H}$ MOR using methanol as a sonication medium (Figure 9b) show more or less uniformly sized particles, whereas using n-butanol (Figure 9c) and water (Figure 9d) larger agglomerates may prevail.

Figure 10 shows the effect of ultrasonication media on the type of pore size distribution. Using methanol as a sonication liquid medium, Figure 10a exhibits one major peak appearing at pore radii ranging between 36.9 and $60.9 \AA$ and centered at $45.9 \AA$. Evidently, there is no appearance of any peaks at lower radius ranges, indicating the absence of diffusion limitation and hence methanol is considered to be the most suitable ultrasonication medium compared to the other media under investigation.

Figure 10b (for n-propanol) shown a major peak appearing between 36.9 and $60.7 \AA$ with a maximum at $45.8 \AA$, but however it shows also another minor peak at a small radius of $17.3 \AA$. This narrow radius peak should have caused some diffusion restriction compared to using methanol (Figure 10a) as a sonication medium. In Figure 10c (for $n$-butanol), the major quantity of pores present in the mordenite catalyst after ultrasonication in n-butanol acquires pore radii in the range of 7.3 to $15.5 \AA$ and centered at $11.1 \AA$. However, there is a minor quantity of larger pores having radii of $36.7 \AA$. The first small major quantity of pores $(7.3-15.5 \AA)$ can be assumed to be responsible for a slower diffusion rate of entrance in and diffusion to the largest outside with difficulty, hence causing the retardation of the overall rate of DME production, compared to the other ultrasoniction alcoholic media.

Figure $10 \mathrm{~d}$ is obtained for the H-MOR ultrasonicated in water. It shows one peak centered at a radius of $25.8 \AA$, and no narrower radii than $25.8 \AA$ appear. This indicates that no appreciable diffusion restriction occurs and water can be used as a medium for many materials that can be easily penetrated, or absorb/adsorb on water.

\section{Effect of ultrasonication period}

Another more effective factor is the ultrasonication period that has been studied between 20 and $60 \mathrm{~min}$. Figure 11 shows that for instance, at $200^{\circ} \mathrm{C}$ reaction temperature all 


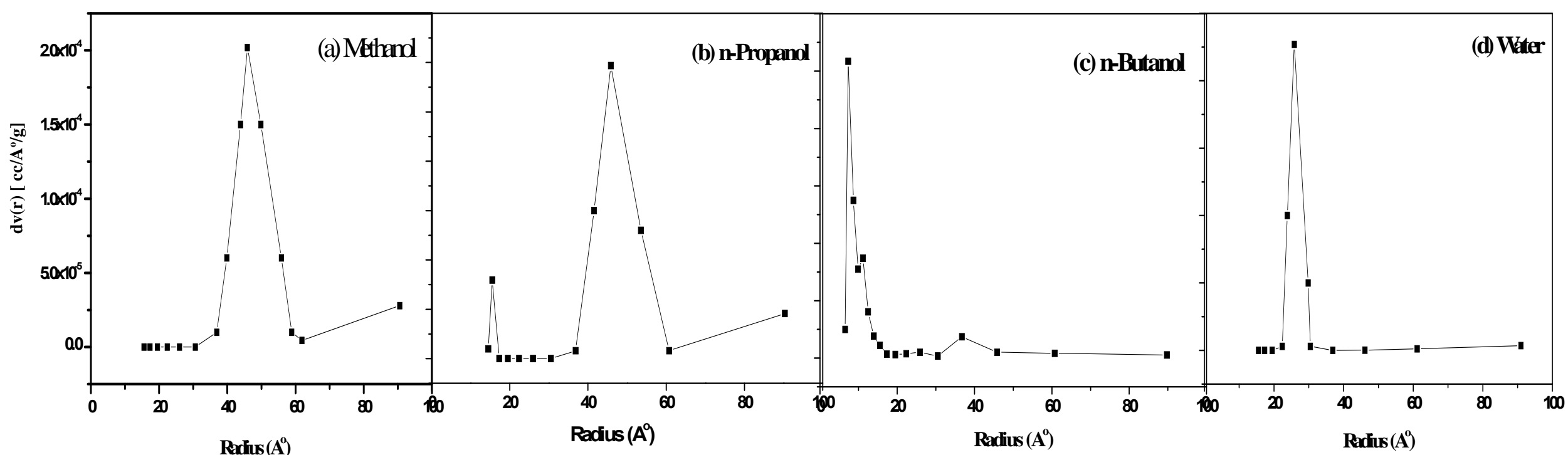

Figure 10. Effect of ultrasonication media (a) methanol, (b) n-propanol, (c) n-butanol and (d) water on the pore size distribution in H-MOR catalyst.

sonicated samples of H-MOR acquire higher catalytic activities than the parent (non-sonicated reference) sample. The increase of sonication period from zero gradually to 20,40 and $60 \mathrm{~min}$ increases the rate of DME formation from $59.9 \%$ to $67.5,80.6$ and $88.8 \%$, respectively. However, also a test for applying a longer period (80 min, not given) has been found to give a DME yield of $61.6 \%$, which is insignificantly different from the yield produced at the same reaction temperature using the parent (Unsonicated) catalyst. This indicates that ultrasonication for excessively longer periods can be deteriorative, most probably due to re-agglomeration of the zeolitic particles (reversing to producing bigger clusters) (Nasikin and Wahid, 2005; Lii and Inui, 1996). It is evident in Figure 11 that beyond $250^{\circ} \mathrm{C}$, the DME yield declines due to production of olefinic hydrocarbons.

Figure 12 shows how ultrasonication period could affect the selectivity of DME and olifinic hydrocarbons production at $300^{\circ} \mathrm{C}$ reaction temperature. Evidently, DME decreases with increasing ultrasonication period to $80 \mathrm{~min}$ due to equivalent increase in the formation of olefinic hydrocarbons via more severe dehydration of the methanol feed (Aboul-Gheit and Aboul-Fotouh, 2012; Aboul-Fotouh, 2014).

Figure 13 shows that the decrease of d-spacing values (determined by $\mathrm{XRD}$ ) via increasing the ultrasonication period gives an important finding that the unit cell of the zeolite has been decreased, that is, the sonification has exerted a structural impact on the crystalline unit cell, which can be very important in many zeolitic applications.
Figure 14 shows the effect of ultrasonication period on pore size distribution of H-MOR catalyst. The unsonicated (parent) zeolite (Figure 14 a) exhibits two peaks at 7.4 and $17.3 \AA$ width pores, whereas the first ultrasonication treatment carried out for 20 min resulted in producing two wider peaks at 15.5 and $19.4 \AA$ in addition to a shoulder at $25.9 \AA$ pore width (Figure 14b). This increase of pore radii by $20 \mathrm{~min}$ ultrasonication resulted in improvement of DME yield at all reaction temperatures.

Again, an increase of ultrasonication time to 40 min resulted in a further production of two wider pore peaks at 15.5 and $30.4 \AA$ (Figure 14c). This increase of pore width via increasing the ultrasoniction time to $40 \mathrm{~min}$ has resulted in wider and wider pores and hence decreased consecutively the diffusion limitation whereby 


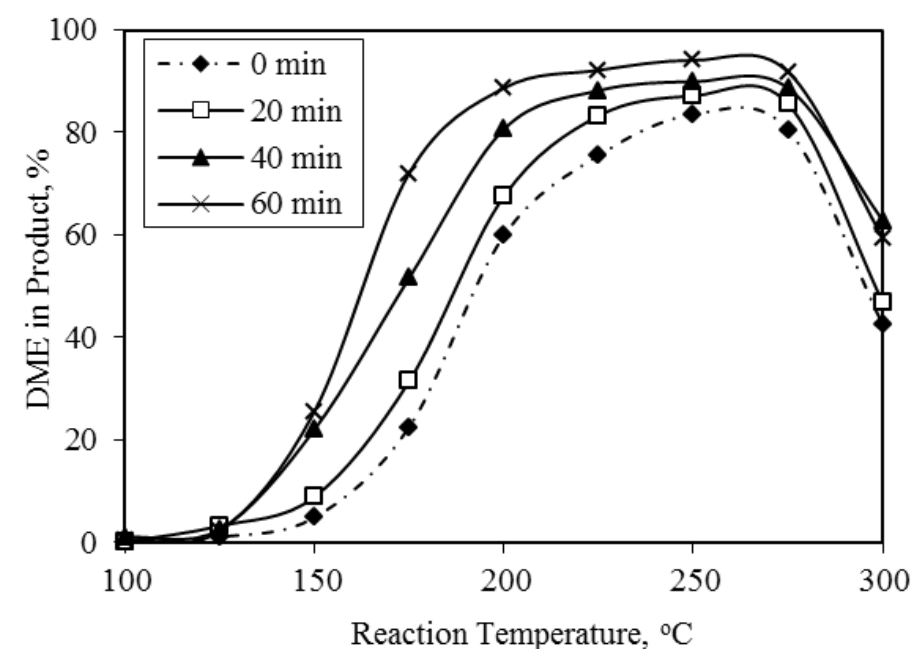

Figure 11. Effect of ultrasonication period on the formation of DME using H-MOR catalyst.

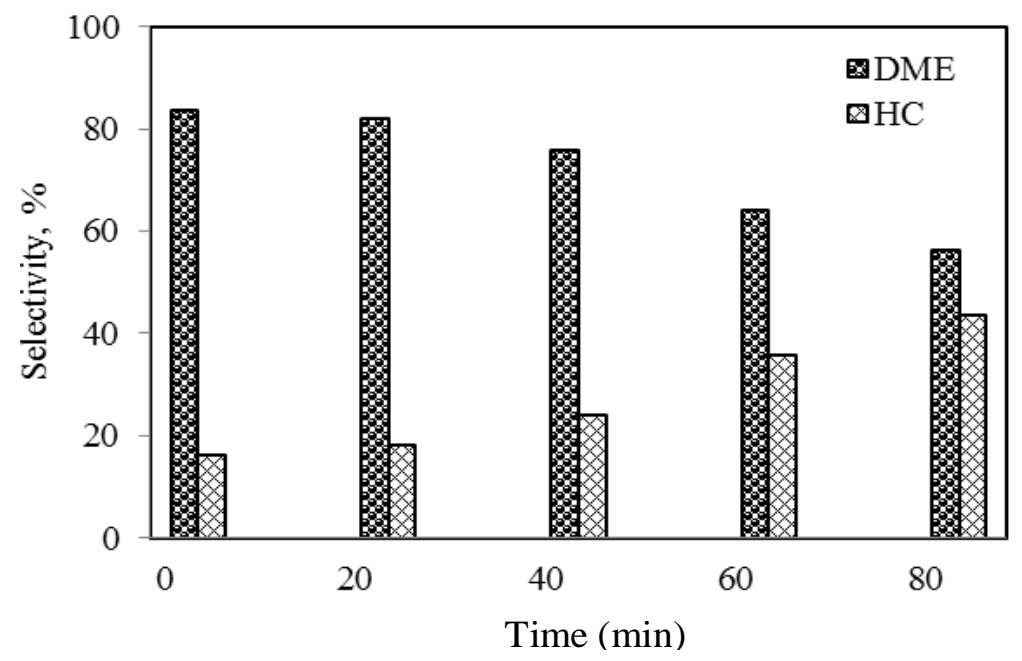

Figure 12. Effect of ultrasonication time on DME and $\mathrm{HC}$ selectivities at $300^{\circ} \mathrm{C}$.

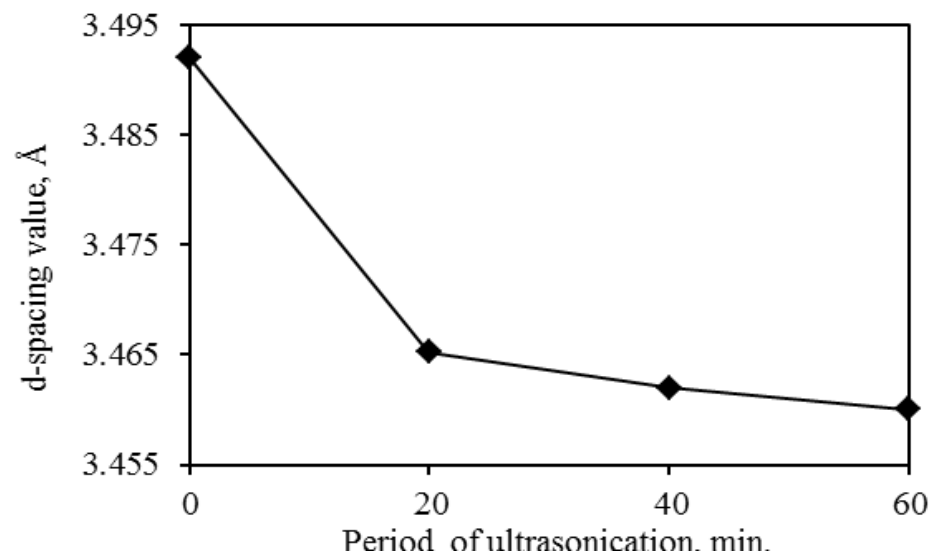

Figure 13. Effect of ultrasonication period on the d-spacing value of H-MOR catalyst. 

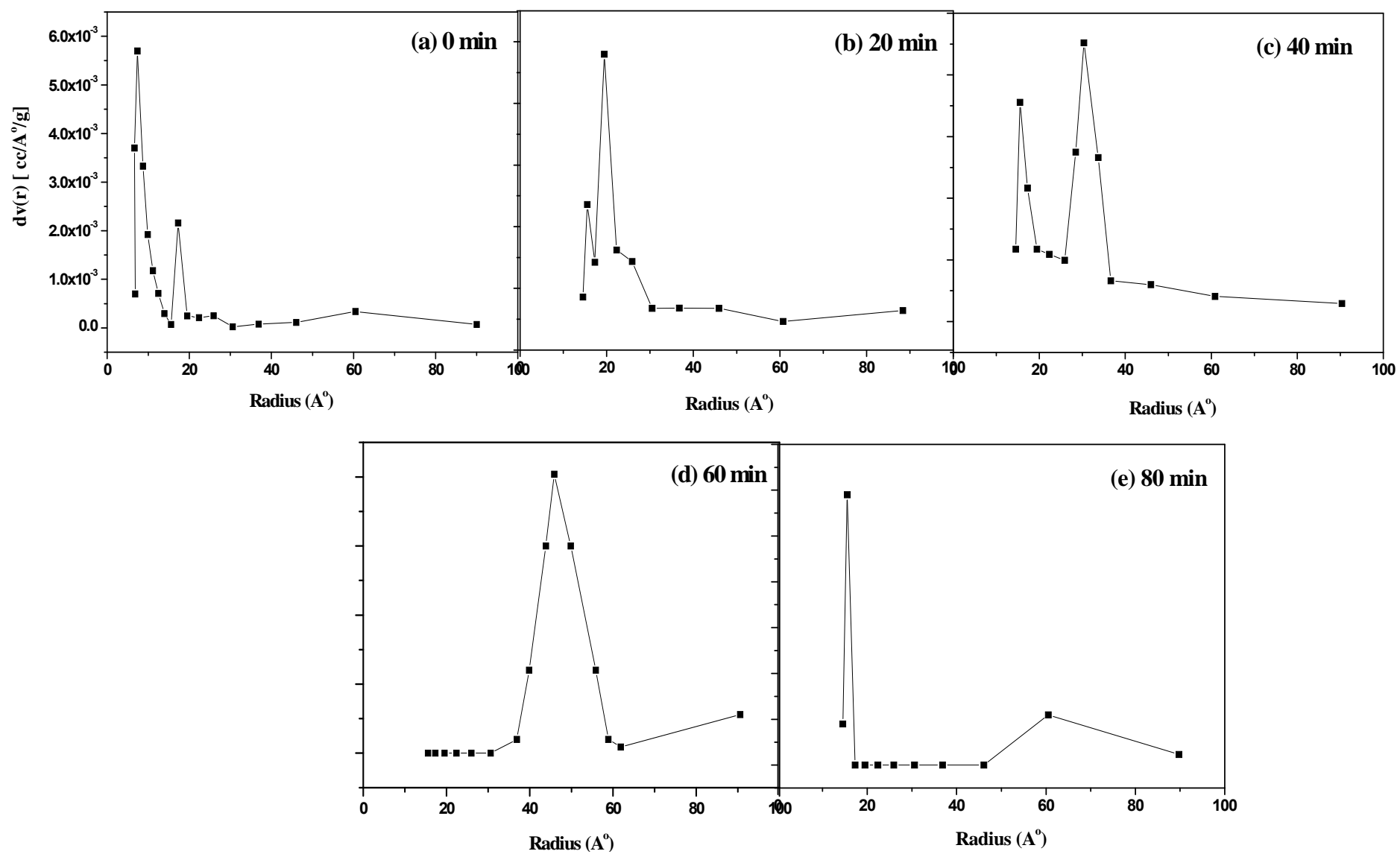

Figure 14. Effect of ultrasonication period on the pore size distribution of H-MOR catalyst.

increasing the yield of DME (Figure 11). A further increase of ultrasonication period to 60 min gives the optimum pore size distribution where no peaks appear at the low radius values but only one single peak covering the pore radius range between 36.9 and $60.9 \AA$ and centered at $45.9 \AA$ (Figure 14d). This wide range excludes diffusion limitation and this catalyst has been found to achieve the highest yield of DME.

Furthermore, ultrasonication for $80 \mathrm{~min}$ (Figure 14e) gives a major peak at $15.5 \AA$ and a much wider low intensity peak covering the pore radius range 46.0 to 89.7 $\AA$ and centered at $60.5 \AA$. This behavior indicates that such longer period of ultrasonication is not in favor of obtaining adequate pore size distribution since a large percentage of the catalytic pores are blocked in the 15.5 $\AA$ peak range, thus being inadequate for the production of DME.

\section{Effect of methanol volume for ultrasonicated H-MOR catalyst}

The volume of the zeolite solvent (methanol) relative to a fixed weight of $\mathrm{H}-\mathrm{MOR}$ has been studied using 5.0, 7.5,
10.0 or $12.5 \mathrm{~cm}^{3}$ methanol/ $0.3 \mathrm{~g} \mathrm{H}-\mathrm{MOR}$ (Figure 15). Evidently, a solvent/H-MOR ratio of $7.5 \mathrm{~cm}^{3} / 0.3 \mathrm{~g}$ can be considered the most favorable. At $200^{\circ} \mathrm{C}$ reaction temperature, it is found that the DME yield comprises $88.8 \%$, whereas this yield drops to $75.7,72.6$ and $69.2 \%$ for solvent/zeolite ratios of $5.0,10.0$ and $12.5 \mathrm{~cm}^{3} / 0.3 \mathrm{~g}$, respectively.

Figure 16 shows that XRD d-spacing value, which is taken as a measure of the unit cell diameter, decreases with increasing the volume of the methanol solvent down to a minimum d-spacing at $7.5 \mathrm{~cm}^{3} / 0.3 \mathrm{~g} \mathrm{H}-\mathrm{MOR}$, then rises again via increasing the volume of solvent to 12.5 $\mathrm{cm}^{3} / 0.3 \mathrm{~g} \mathrm{H}-M O R$. These data are compatible with the activity of the catalysts which decreases with increasing the obtained nano-sized particles.

Moreover, the SEM photographs (Figure 17) show that ultrasonication of the $5 \mathrm{~cm}^{3} / 0.3 \mathrm{~g}$ sample gives highly agglomerated clusters whereas the $7.5 \mathrm{~cm}^{3} / 0.3 \mathrm{~g}$ sample gives much smaller crystallites. However, the 12.5 $\mathrm{cm}^{3} / 0.3 \mathrm{~g}$ sample shows somewhat larger particles than the $7.5 \mathrm{~cm}^{3} / 0.3 \mathrm{~g}$ sample which is in favor of the higher activity of the latter sample.

Figure 18 gives the pore size distribution curves for $\mathrm{H}$ MOR solvated in $5.0,7.5$ and $12.5 \mathrm{~cm}^{3}$ methanol/ $0.3 \mathrm{~g} \mathrm{H}$ - 


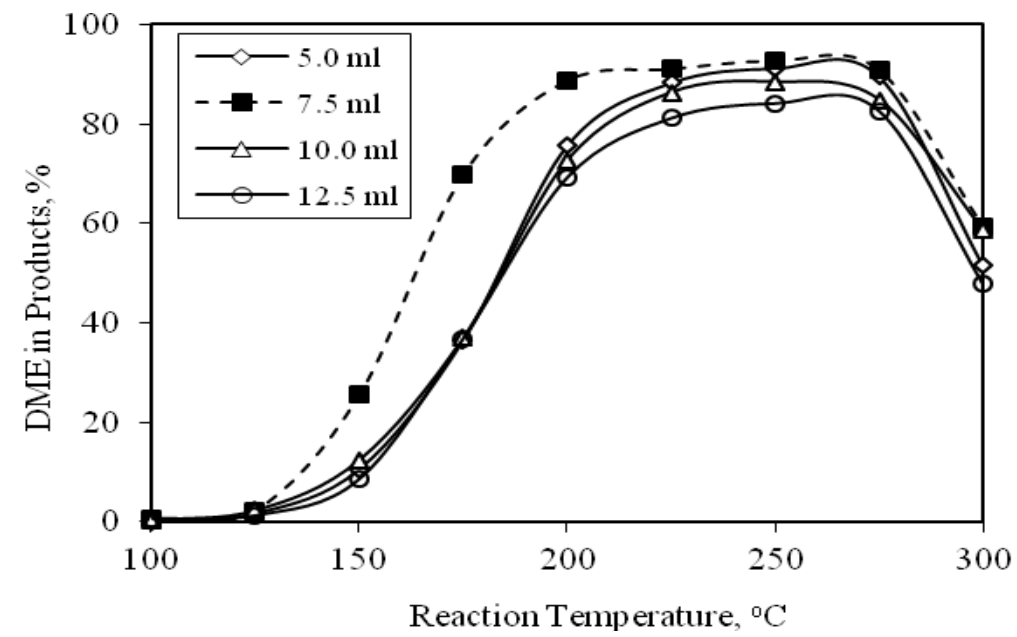

Figure 15. Effect of methanol volume on the formation of DME using ultrasonicated H-MOR catalyst.

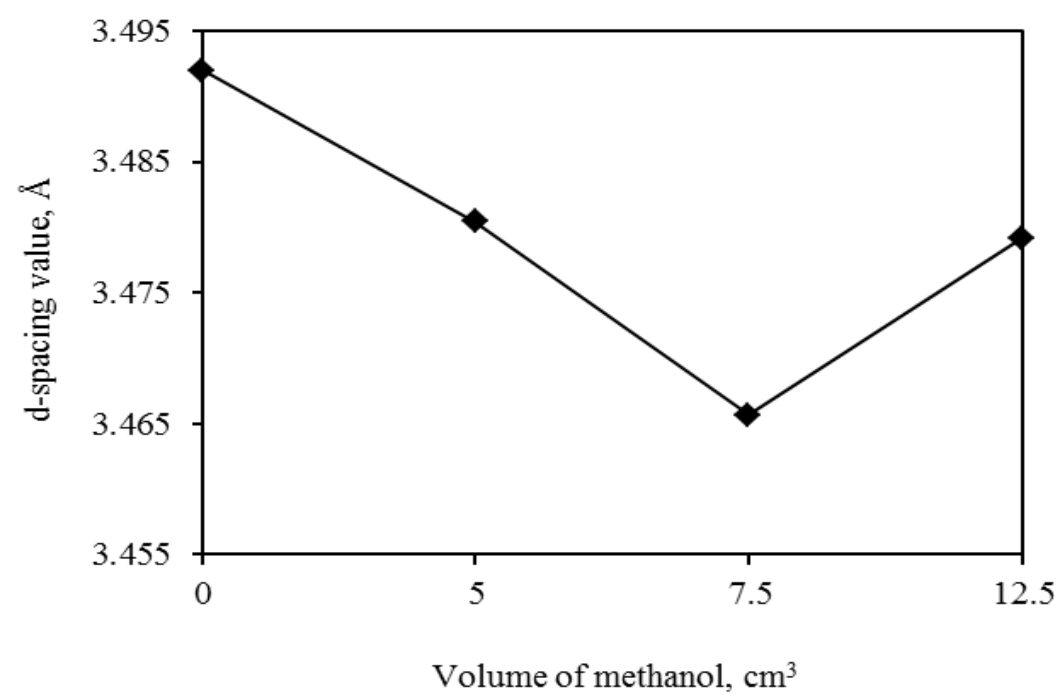

Figure 16. Effect of methanol volume on the d-spacing value of ultrasonicated $\mathrm{H}-\mathrm{MOR}$ catalyst.

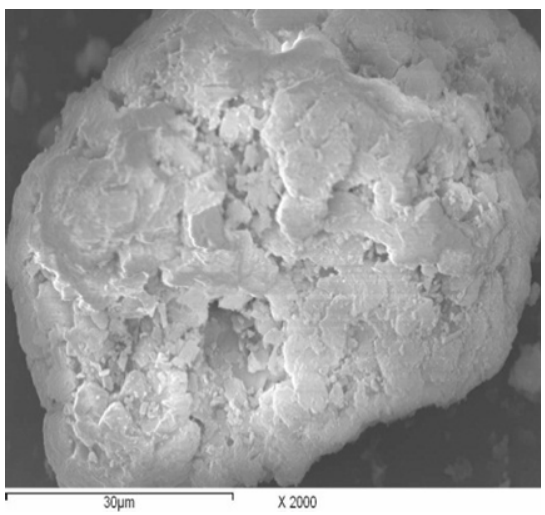

(a) $5.0 \mathrm{~cm}^{3}$

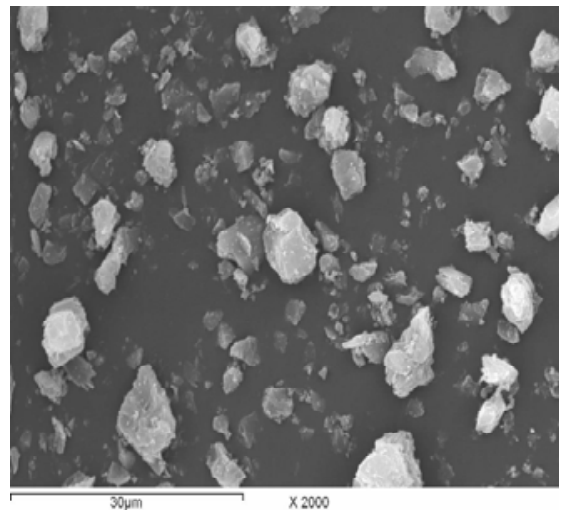

(b) $7.5 \mathrm{~cm}^{3}$

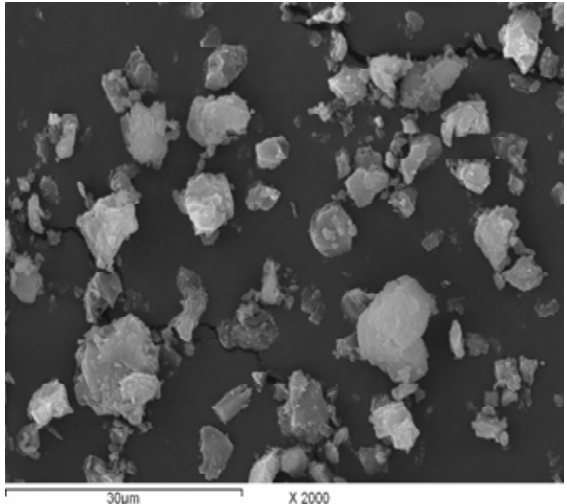

(c) $12.5 \mathrm{~cm}^{3}$

Figure 17. SEM of ultrasonicated H-MOR using different volume of methanol. 


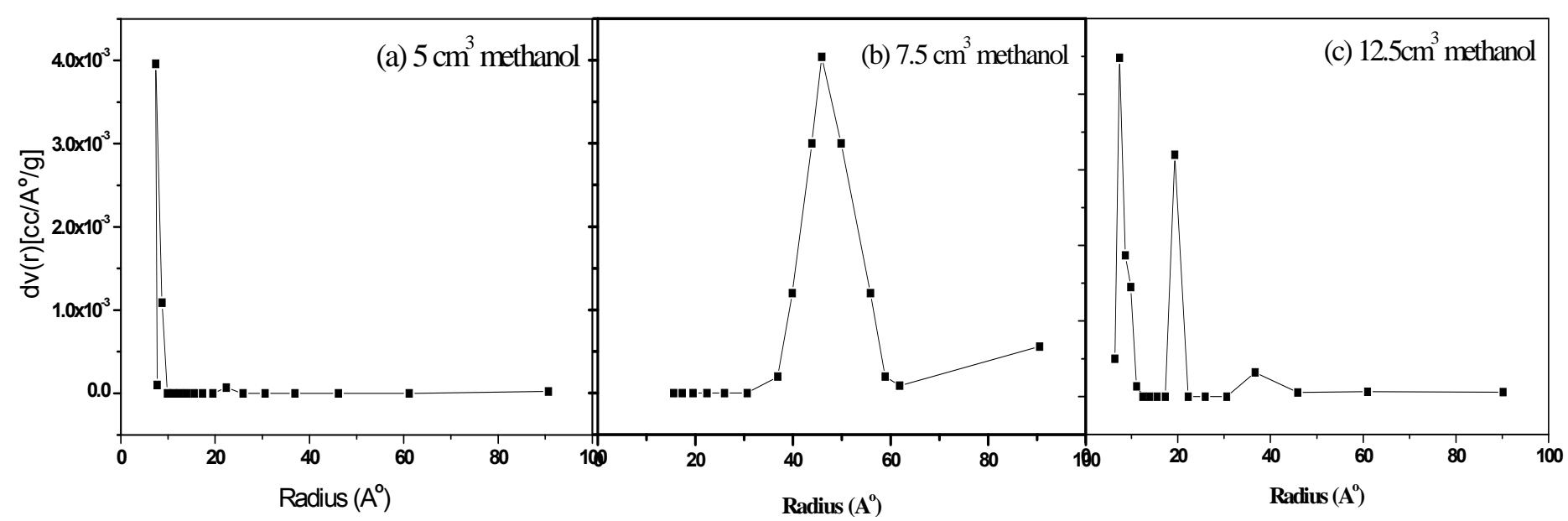

Figure 18. Effect of methanol volume on the pore size distribution of ultrasonicated H-MOR catalyst.

MOR. The most adequate curve has been obtained using $7.5 \mathrm{ml} / 0.3 \mathrm{~g}$ mordenite which extends through a strong wide pore radius range 36.9 to $60.9 \AA$ centered at $45.8 \AA$ (Figure 18b). This curve does not show any peaks at the low radius range which indicates that the ultrasonicated zeolite does not acquire narrow pores which may cause diffusion restriction and hence the pore distribution in Figure $18 \mathrm{~b}$ can be an ideal one in contradistinction to the distribution curves exhibiting peaks at radii smaller than $20 \AA$ such as those appearing in Figures $18 a$ and c.

\section{Conclusion}

All ultrasonication conditions of $\mathrm{H}-\mathrm{MOR}$ zeolite have been correlated with the catalytic activity for also dehydration of methanol as a model reaction testing the efficiency of ultrasonication as a tool for activating the catalytic activity of the H-MOR. The activities of the ultrasonicating media are methanol $>$ ethanol $>$ n-propanol $>$ n- butanol. The ultrasonication period effectiveness has been found 60 min and the best amount of methanol as a medium for ultrasonication is $7.5 \mathrm{~cm}^{3} / 0.3 \mathrm{~g}$ of the H-MOR catalyst. XRD d-spacing values, crystallite size and SEM photographs were correlated with the catalytic activity at the different variables and found in accordance. Dspacing always decreased when agglomeration photographs decreased.

\section{Conflict of Interests}

The authors have not declared any conflict of interests.

\section{REFERENCES}

Aboul-Fotouh SM (2003). Cyclohexene reactivity using catalysts containing Pt, Re and PtRe supported on Na- and $\mathrm{H}$ - mordenite. Journal of Chinese Chemical Society, 50: 1151-1158.

Aboul-Fotouh SMK (2013). Effect of ultrasonic irradiation and/or halogenation on the catalytic performance of $\mathrm{y}$-AI2O3 for methanol dehydration to dimethyl ether. J Fuel Chem Technol., 41:1077-1084. http://dx.doi.org/10.1016/S1872-5813(13)60045-6

Aboul-Fotouh SMK (2014). Production of Dimethylether (DME) as a Clean Fuel Using Sonochemically Prepared $\mathrm{CuO}$ and/or $\mathrm{ZnO}$ modified $\gamma$-Alumina catalysts. J Fuel Chem Technol., 42: 350-356. http://dx.doi.org/10.1016/S1872-5813(14)60020-7

Aboul-Fotouh SMK, Aboul-Gheit NAK, Hassan MMI (2011). Conversion of methanol using modified H-MOR zeolite catalysts. Chinese Journal of Catalysis, 32: 412-417. http://dx.doi.org/10.1016/S1872-2067(10)60187-8

Aboul-Fotouh SMK, Hassan MMI (2010). Conversion of Methanol on $\mathrm{CuO} / \mathrm{H}-\mathrm{MOR}$ and $\mathrm{CuO} / \mathrm{H}-\mathrm{ZSM}-5$ Catalysts. Acta Chim. Solv., 57: 872-879.

PMid:24061890

Aboul-Gheit AK, Aboul-Fotouh SM (2012). Insight in cyclohexene hydroconversion process using catalysts containing $0.35 \% \mathrm{Pt}$ on amorphous and zeolite supports. Journal of the Taiwan Institute of Chemical Engineers, 43: 711-717. http://dx.doi.org/10.1016/j.jtice.2012.03.007

Amin A, Ali A, Aboul-Fotouh S, Ebeid EF (1994). Surface studies and nature of active sites of supported heteropolyacids as catalysts in methanol dehydration, Collect. Czech. Chem. Commun., 59: 820832. http://dx.doi.org/10.1135/cccc19940820

Bandiera J, Naccache C (1991). Kinetics of methanol dehydration on dealuminated $\mathrm{H}$-mordenite: Model with acid and basic active centers, Applied Catalysis A: general, 69: 139-148. http://dx.doi.org/10.1016/S0166-9834(00)83297-2

Bonrath W (2005). Ultrasound supported catalysis. Ultrason. Sonochem., 12:103-106.

http://dx.doi.org/10.1016/j.ultsonch.2004.03.008 PMid:15474961

Dantsin G, Suslick KS (2000). Sonochemical preparation of a nanostructured bifunctional catalyst. J. Am. Chem. Soc., 122: 52145215. http://dx.doi.org/10.1021/ja994300w

Ebeid MF, Ali A, Amin A, Aboul-Fotouh S (1993). Heteropoly acids supported on a-Al2O3 as solid acid catalysts for methanol transformation. Collect. Czech. Chem. Commun., 58: 2079-2089. http://dx.doi.org/10.1135/cccc19932079

Fei J, Hou Z, Zhu B, Lou H, Zheng X (2006). Synthesis of dimethyl ether (DME) on modified HY zeolite and modified HY zeolitesupported $\mathrm{Cu}-\mathrm{Mn}-\mathrm{Zn}$ catalysts. Applied Catalysis A: general, 
304: 49-54.

http://dx.doi.org/10.1016/j.apcata.2006.02.019

Freel J (1972). Chemisorption on supported platinum: I. Evaluation of a pulse method. J Catal., 25:139-148.

http://dx.doi.org/10.1016/0021-9517(72)90211-4

Fu Y, Hong T, Chen J, Auroux A, Shen J (2005). Surface Acidity and the Dehydration of Methanol to Dimethyl Ether. Thermochimica Acta, 434: 22-26.

http://dx.doi.org/10.1016/j.tca.2004.12.023

Fu Y, Hong T, Chen J, Auroux A, Shen J (2005). Surface acidity and the dehydration of methanol to dimethyl ether. Thermochimica Acta, 434:22-26. http://dx.doi.org/10.1016/j.tca.2004.12.023

Jiang S, Hwang J, Jin T, Cai T, Cho W, Baek Y, Park S (2004). Dehydration of Methanol to Dimethyl Ether over ZSM-5 Zeolite. Bull. Korean Chem. Soc., 25:185-189. http://dx.doi.org/10.5012/bkcs.2004.25.2.185

Keshavarz AR, Rezaei M, Yaripour F (2011). Preparation of nanocrystalline $\mathrm{y}$-Al2O3 catalyst using different procedures for methanol dehydration to dimethyl ether. Journal of Natural Gas Chemistry, 20: 334-338.

http://dx.doi.org/10.1016/S1003-9953(10)60157-0

Khandan N, Kazemeini M, Aghaziarati M (2008). Determining an optimum catalyst for liquid-phase dehydration of methanol to dimethyl ether. Applied Catalysis A: general, 349: 6-12. http://dx.doi.org/10.1016/j.apcata.2008.07.029

Khandan N, Kazemeini M, Aghaziarati M (2009). Synthesis of Dimethyl Ether over Modified H-Mordenite Zeolites and Bifunctional Catalysts Composed of $\mathrm{Cu} / \mathrm{ZnO} / \mathrm{ZrO} 2$ and Modified H-Mordenite Zeolite in Slurry Phase. Catalysis Letters, 129 (1-2): 111-118. http://dx.doi.org/10.1007/s10562-008-9779-8

Khom-in J, Praserthdam $\mathrm{P}$, Panpranot $\mathrm{J}$, Mekasuwandumrong $\mathrm{O}$ (2008). Dehydration of methanol to dimethyl ether over nanocrystalline $\mathrm{Al} 2 \mathrm{O} 3$ with mixed $Y$ - and $X$-crystalline phases. Catalysis Communications, 9:1955-1958. http://dx.doi.org/10.1016/j.catcom.2008.03.009

Kim SD, Baek SC, Lee YJ, Jun KW, Kim MJ, Yoo IS (2006). Effect of Gamma-alumina Content on Catalytic Performance of Modified ZSM5 for Dehydration of Crude Methanol to Dimethyl Ether. Applied Catalysis A: general, 309: 139-143.

http://dx.doi.org/10.1016/j.apcata.2006.05.008

Kumar N, Masloboischikova OV, Kustov LM, Heikkila T, Salmi T, Murzin DY (2007). Synthesis of Pt modified ZSM-5 and beta zeolite catalysts: influence of ultrasonic irradiation and preparation methods on physico-chemical and catalytic properties in pentane isomerization. Ultrason. Sonochem., 14:122-130.

http://dx.doi.org/10.1016/j.ultsonch.2006.05.001

PMid:16807049

Ladera R, Finocchio E, Rojas S, Fierro JLG, M. Ojeda M (2012).

Lertjiamratn K, Praserthdam P, Arai M, Panpranot J (2010). Modification of acid properties and catalytic properties of AIPO4 by hydrothermal pretreatment for methanol dehydration to dimethyl ether, Applied Catalysis A: general, 378:119-123.

http://dx.doi.org/10.1016/j.apcata.2010.02.013

Lii JL, Inui T (1996). Enhancement in methanol synthesis activity of a copper/zinc/aluminum oxide catalyst by ultrasonic treatment during the course of the preparation procedure. Applied Catalysis A: general, 139: 87-96. http://dx.doi.org/10.1016/0926-860X(95)00318-5

Liu D, Yao C, Zhang J, Fang D, Chen D (2011). Catalytic dehydration of methanol to dimethyl ether over modified $\mathrm{Y}$-Al2O3 catalyst. Fuel, 90: 1738-1742.

http://dx.doi.org/10.1016/j.fuel.2011.01.038

Mollavali M, Yaripour F, Mohammadi-Jam S, Atashi H (2009). Relationship between surface acidity and activity of solid-acid catalysts in vapor phase dehydration of methanol. Fuel Processing Technology, 90:1093-1098. http://dx.doi.org/10.1016/j.fuproc.2009.04.018

Nasikin M, Wahid A (2005). Effect of ultrasonic during preparation on Cu-based catalyst performance for hydrogenation of $\mathrm{CO}$ to methanol. AJChE 5:111-115.
Paddock C (2012). Diesel Exhaust Fumes Cause Cancer, WHO, Medical News Today

Ramos FS, Farias AMDD, Borges LEP, Monteiro JL, Fraga MA, SousaAguiar EF, Appel LG (2005). Role of dehydration catalyst acid properties on one-step DME synthesis over physical mixtures. Catalysis Today, 101: 39-44.

http://dx.doi.org/10.1016/j.cattod.2004.12.007

Raoof F, Taghizadeh M, Eliassi A, Yaripour F (2008). Effects of temperature and feed composition on catalytic dehydration of methanol to dimethyl ether over $\mathrm{y}$-alumina. Fuel, 87: 2967-2971. http://dx.doi.org/10.1016/j.fuel.2008.03.025

Simona B, Antonella G (2003). Preparation of highly dispersed $\mathrm{CuO}$ catalysts on oxide supports for de-NOx reactions. Ultrason. Sonochem., 10: 61-64. http://dx.doi.org/10.1016/S1350-4177(02)00150-5

Sun Kou MR, Mendioroz S, Salerno P, Munoz V (2003). Catalytic activity of pillared clays in methanol conversion. Applied Catalysis A: general, 240: 273-285. http://dx.doi.org/10.1016/S0926-860X(02)00466-0

Supported niobium catalysts for methanol dehydration to dimethyl ether: FTIR studies of acid properties, Catalysis Today.

Wang AW, Weigel S, Muraro G (2002). Molecular Sieves as Catalysts for Methanol Dehydration in the LPDME- Process. Air Products and Chemicals Inc., DE- FC22-95 PC93052.

Xu M, Lunsford JH, Goodman DW, Bhattacharyya A (1997). Synthesis of dimethyl ether (DME) from methanol over solid-acid catalysts, Applied Catalysis A: general, 149: 289-301. http://dx.doi.org/10.1016/S0926-860X(96)00275-X http://dx.doi.org/10.1016/S0926-860X(96)00276-1

Yaripour F, Baghaei F, Schmidt I, Perregaard J (2005). Synthesis of dimethyl ether from methanol over aluminium phosphate and silicatitania catalysts. Catalysis Communications, 6 (8):542-549.

http://dx.doi.org/10.1016/j.catcom.2005.05.003

Yaripour F, Baghaei F, Schmidt I, Perregaard J (2005). Catalytic dehydration of methanol to dimethyl ether (DME) over solid-acid catalysts. Catalysis Communications, 6 (2): 147-152. http://dx.doi.org/10.1016/j.catcom.2004.11.012

Zhang H, Zhu LQ, Li WP, Liu HC (2008). Sonochemical Fabrication and Electrochemical Performance of Electrode Materials Containing Rare Earth Yttrium. Acta Phys. -Chim. Sin., 24: 1425-1431.

Zhu Z, Li D K, Liu J, Wei Y j, Liu S H (2012). Investigation on the regulated and unregulated emissions of a DME engine under different injection timing, Applied Thermal Engineering, 35: 9-14. http://dx.doi.org/10.1016/j.applthermaleng.2011.08.015. 